\title{
EMPLOYING POLITICS OF IDENTITY AND NURTURING RELIGIOUS PIETY: AN EXPERIENCE OF THE MAJELIS PENGKAJIAN TAUHID DAN TASAWUF INDONESIA IN ACEH
}

\author{
Muhammad Suhaili Sufyan \\ State Institute of Islamic Studies Langsa, Aceh, Indonesia \\ E-mail: suhaily@iainlangsa.ac.id \\ Zulkarnaini \\ State Institute of Islamic Studies Langsa, Aceh, Indonesia \\ E-mail: zul.abd.ch@gmail.com \\ Mawardi \\ State Institute of Islamic Studies Langsa, Aceh, Indonesia \\ E-mail: mawardi@iainlangsa.ac.id
}

\begin{abstract}
This article discusses the identity politics of the Majelis Pengkajian Tauhid dan Tasawuf Indonesia (MPT'TI) or the Indonesian Council for the Study of Tauhid and Tasawuf in nurturing piety among the Acehnese community. The MPTTI emphasizes the mystical realm of Islamic doctrines and has been considered to spread wujüdiyya or pantheistic ideas of God, which are regarded as deviant by the mainstream or fiqh-oriented groups. However, this organization was able to develop a Sufistic ideology in Aceh and introduced it to a broader audience at national and international levels. Viewed from the perspective of identity politics, this study argues that marginalization has led the MPTTI to fight for equality and challenge the mainstream groups. Meanwhile, the phenomenological approach was used by the study to highlight the identity politics of the MPTTI, which were also revealed to have been employed in religious, social, cultural, and political spheres. Consequently, the mainstream figh-oriented groups have gradually acknowledged the MPTTI's effort to pursue equality, and this council has also successfully established political alliances with the government and other organizations.
\end{abstract}

Keywords: Politics of identity, Sufistic ideology, piety. 


\section{Introduction}

There are no debates on understanding the meaning of Islam at the theological-normative level. At the practical-interpretive level, the word 'Islam' is understood differently because of the differences in perceptions and interpretations. These differences have contributed to the emergence of various sects. ${ }^{1}$ The differences in understanding Islam have been observed existing in the religious dynamics in Aceh. The existence of Majelis Pengkajian Tauhid Tasawuf Indonesia (Council for the Study of Tauhid-Tasawuf) is one of the organizations within the religious dynamics. In the early implementation of the Islamic bylaw in Aceh, the existence of Majelis Pengkajian Tauhid Tasawuf Indonesia-hereinafter abbreviated as MPTT-has not attracted the interest of the scholars. Researchers were mainly interested in investigating the Islamic bylaw implementation rather than paying their attention to the phenomenon of the tasawnuf groups. ${ }^{2}$ This implies that the implementation of Islamic bylaw does not only have an impact on normative levels but also provides a space for the sharia groups to be more authoritative. ${ }^{3}$

The study of the MPTT movement was carried out by Moch Nur Ichwan (2016), ${ }^{4}$ Sehat Ihsan Shadiqin (2018), ${ }^{5}$ and Rahmawati,

\footnotetext{
${ }^{1}$ Etymologically, the term "sect" can be derived from the Latin word "sequi" which means "to separate" or "to cut". However, the term sect is often used with a negative connotation. According to Hill, a sect is a term that is used widely to describe any group that has different perspectives from the general perspective or has the same interests. This term is used by philosophical, political, and religious groups. In particular, the word "sect" refers to religious groups that are separate from the dominant church. Michael Hill, "Sect", Encyclopedia of Religion (New York: Simon \& Schuster Macmillan, 1996), 154-155.

2 Sehat Ihsan Shadiqin, "Tasawuf di Era Syariat: Tipologi Adaptasi dan Tranformasi Gerakan Tarekat dalam Masyarakat Aceh Kontemporer," Jurnal Substansia, Vol. 20, No. 1 (2018), 68.

${ }^{3} \mathrm{Al}$ Makin, "Returning to the Religion of Abraham: Controversies over the Gafatar Movement in Contemporary Indonesia," Islam and Christian-Muslim Relations, Vol. 30, No. 1 (2019), 88, https://www.tandfonline.com/doi/full/10.1080/09596410. 2019.1570425 .

${ }^{4}$ Mohd Nur Ichwan, "Neo-Sufism, Shariatism, and Ulama Politics: Abu Shaykh Amran Waly and the Tauhid-Tasawuf Movement in Aceh", in Kees van Dijk and Nico J.G. Kaptein (eds.), Islam, Politics and Change (Leiden: Leiden University Press, 2016), 231-232.

5 Shadiqin, "Tasawuf di Era Syariat, 67-78.
} 
et.al. $(2018)^{6}$ in 2012. Their studies concluded that MPTT was a Sufi group following tarekat Naqshbandiyya. The tarekat Naqshbandiyya itself was acknowledged in Aceh. Some of the traditional boarding schools (dayah) practiced MPTT in their religious rituals. ${ }^{7}$ The was no strong resistance from the people in Aceh towards the MPTT movement in terms of the ways they practiced their religious activities, such as sulük (a spiritual path to Allah) and tawajjuhan (total submission to Allah). The ulama began resisting against MPT'T as they suspected that MPTT introduced the concepts of wijudiyya (pantheistic ideas about God), fana ' (state of annihilation), and baqa' (state of permanence) locally expressed as "teusom hamba leumah rabbi."

The concept of wabdat al-wujüd, in Aceh, is considered taboo and deviant from the mainstream religious principles. This triggered controversy and many ulemas opposed MPTT because it is considered heretical and deviates from the mainstream religious ideology that adheres to orthodox Sufism. ${ }^{9}$ It was through the opposition from many ulemas, MPT'T had to face marginalization from a stereotype as heresy to the limitation of rights to perform their religious rituals. ${ }^{10} \mathrm{~A}$ forced dissolution of MPTT in Bireuen and the prohibition to perform religious activities in Pidie Jaya and Langsa were some of the examples showing the situation MPTT faced. ${ }^{11}$ However, under such unfavorable circumstances of domination, discrimination, and suspension of rights, MPTT was able to strengthen its identity at the local, national, and international levels. The establishment of MPTT chapters in many districts and cities

${ }^{6}$ Rahmawati, Kasim Yahiji, and Mustakimah, "Makna Zikir Bagi Jemaah Tarekat Naqshabandīyah Khālīdīyah Majelis Pengkajian Tauhid Tasawuf Indonesia di Kota Gorontalo," TEOSOFI: Jurnal Tasawnf dan Pemikiran Islam, Vol. 8, No. 2 (2018), 325350, http://jurnalfuf.uinsby.ac.id/index.php/teosofi/article/view/234.

7 Suraiya IT., Syamsul Rijal, and Zaenuddin Hudi Prasojo, "Sufism and Religious Practices in Modern Lifestyle," Religió: Jurnal Studi Agama-agama, Vol. 9, No. 1 (2019), 01-21, http://jurnalfuf.uinsby.ac.id/index.php/religio/article/view/1231.

${ }^{8}$ Observation of Participants in the Study of Tauhid Tasawuf and Rateb Siribee at the Islamic Center Lhokseumawe, August 13, 2017

${ }^{9}$ Ichwan, "Neo-Sufism, Shariatism, 222

${ }^{10}$ Interview with Tgk. Syukri (Chair of the MPTT Aceh Besar-Banda Aceh Region), Banda Aceh, June 28, 2019.

${ }^{11}$ Interview with Tgk. Usman (an alumnus of the Darussalam Labuhan Haji Islamic Boarding School in South Aceh, as well as the Implementation of the Taubid Tasawuf and Rateb Siribee Study Activities at the Islamic Center Lhokseumawe), Banda Aceh, August 13, 2017. 
across Indonesia and other countries such as Malaysia and Thailand prove to the affirmation of the claim. A gradual but positive response from the local administration and the society towards MPTT was observed in recent times through a symbolic acceptance. MPT'T was allowed to carry out its activities at the Baiturrahman mosque in Banda Aceh, which implies the government and community recognition for this organization. ${ }^{12}$

Being a minority and the struggle for equality and recognition is the concept of the politics of identity. The politics of identity is understood as a way employed by MPTT to fight for its Islamic identity that has been long dominated by the sharia groups. Maarif states that there is always an identity that is fought for in the dynamics of domination and discrimination. ${ }^{13}$ Brunila and Rossi opine that the politics of identity focuses on the feminists and other minority groups' struggle for equal rights in the public sphere. ${ }^{14}$ In the MPTT context, it is through the struggle for equality in socio-religious that MPTT practiced the politics of identity. Therefore, this article aims to find out the identity and political movement of the Indonesian Tauhid Tasawwuf Study Council to fight for equality. The phenomenological approach was used to obtain all information related to the politics of identity of MPTT. ${ }^{15}$ Thus, all the information related to the events and activities practiced by MPTT in religious life in Aceh were investigated.

\section{The Emergence of the Indonesian Tauhid Tasawwuf Study Council}

The development of MPTT cannot be separated from the role of Abuya Amran Waly, the founder of the MPTT ideology. It is the charming charisma that the followers of Abuya Amran found that paves the way for Abuya Amran to promote his ideological beliefs. The lineage showed a positive contribution to Abuya Amran to attract

\footnotetext{
12 Makin, "Returning to the Religion, 88.

13 Ahmad Syafii Maarif, "Politik Identitas dan Masa Depan Pluralisme Indonesia," in Ihsan Ali-Fauzi dan Samsu Rizal Panggabean (eds.), Politik Identitas dan Masa Depan Pluralisme (Jakarta: Democracy Project, 2012), 4.

14 Kristiina Brunila and Leena-Maija Rossi, "Identity Politics, the Ethos of Vulnerability, and Education," Educational Philosophy and Theory, Vol. 50, No. 3 (2018): 287-298, https://www.tandfonline.com/doi/full/10.1080/00131857.2017. 1343115 .

15 Peter Connolly, Aneka Pendekatan Studi Agama (Yogyakarta: LKiS, 2002), 202
} 
his followers to join MPTT. Abuya Amran was born on August 21, 1947, a son of Syaikh Muda Waly Alkhalidi (1917-1961). Syaikh Muda Waly al-Khalidi was a great Acehnese religious scholar during the old order era. He was the founder of Darussalam Labuhan Haji Boarding School in South Aceh.

Based on the lineage, it can be ascertained that Abuya Amran was introduced to Sufi teachings derived from an early age. He learned Sufi from other Sufi scholars, such as Abu Syekh Zakaria Labai Sati (West Sumatra), Imam Syamsuddin (Sangkalan Abdiya), and Abu Daud Zamzami. He also based his understanding on reading the Sufism books, including those written by Tgk. Ibrahim Sam'ani, the grandfather of Habib Sinagan. ${ }^{16}$ His reading inspired him to initiate and form MPT'TI. Amran was actively involved in politics and became a local representative in South Aceh Regency from 1982 to 1987. It is through his active involvement in politics, he learned and understood about bureaucracy and organizational management. ${ }^{17}$

\section{The Politics of Identity to Fight for Equality}

The politics of identity focuses on the issue of achieving equality or recognition in the public sphere. ${ }^{18}$ The politics of identity is often described as the condition through which certain groups are discriminated against and dominated by mainstream groups that make them marginalized. Maarif mentions that the politics of identity was marked by a movement of the black people against capitalism dominated by white people. ${ }^{19}$ On the other hand, Tanja A. Börzel and Thomas Risse said that the politics of identity was rooted in Europe as the minority groups struggled for their right to be recognized by the state. ${ }^{20}$ This is in line with the MPTT movement who struggle to maintain its identity within the sharia group domination.

Facing the sharia group domination, MPTT struggled to be recognized as part of the plurality. The sectoral ego often leads to

\footnotetext{
16 Abuya Amran's Speech in Explaining the History of the Tauhid Tasawuf Development at the Islamic Center Lhokseumawe, March 8, 2017.

${ }^{17}$ Ichwan, "Neo-Sufism, Shariatism, and Ulama Politics", 233.

18 Brunila and Rossi, "Identity Politics", 287-298.

${ }^{19}$ Maarif, "Politik Identitas".

20 Tanja A. Börzel and Thomas Risse, "Identity Politics, Core State Powers, and Regional Integration: Europe and Beyond," JCMS: Journal of Common Market Studies, Vol. 58, No. 1 (2020), 21-40, https://onlinelibrary.wiley.com/doi/abs/10.1111/ jcms.12982.
} 
suspicion and strengthen sectoral identity. ${ }^{21}$ The sharia majority groups demand that MPT'T only teach Islamic law, even though MPT'T's teaching of Sufism was based on Islamic law. ${ }^{22}$ In contrast, MPT'T views that any ritual cannot be only understood logically based on Islamic law. Mystical elements, according to MPTT, must be considered to understand each religious activity. This signifies that differences in interpretations lead to a different understanding of the same concept. ${ }^{23}$ Each group tends to strongly uphold its belief as true. Consequently, this situation often leads to horizontal conflicts within the religious dynamics in Indonesia. ${ }^{24}$

To fight the negative stigma labeled by sharia groups, MPTT struggled to strengthen its self-identity, challenging domination and discrimination. The forms of politics of identity in Aceh cover the following themes:

\section{Self-strengthening in the Family Relations}

Family relations are important issues in achieving success. Bourdieu's habitus makes it clear that family is a social capital constructing a structure. ${ }^{25}$ In MPT'T, the family is seen and used to seek influence and avoid resistance from the majority. It is the strategy employed by MPTT to make the majority rethink their firm stance against MPT'T, even though MPTT continued recruiting new members. The interview with the son of Abuya Muda Waly AlKhalidi, revealed an uncertain attitude of the sharia groups towards

${ }^{21}$ Moh. Rafli Abbas, "Ruang Publik dan Ekspresi Politik Identitas: Studi tentang Pergulatan Identitas Ke-Papua-an di Yogyakarta)," Society, Vol. 4, No. 1 (2016), 2334, https://society.fisip.ubb.ac.id/index.php/society/article/view/33.

22 Ichwan, "Neo-Sufism, Shariatism, and Ulama Politics".

23 Muh. Khamdan and Wiharyani Wiharyani, "Mobilisasi Politik Identitas dan Kontestasi Gerakan Fundamentalisme," al-Tabrir: Jurnal Pemikiran Islam, Vol. 18, No. 1 (2018), 193, http://jurnal.iainponorogo.ac.id/index.php/tahrir/article/view/ 1198.

${ }^{24}$ Muhammad Muntahibun Nafis and Muhammad Ainun Najib, "Pemikiran Sufistik dan Toleransi Beragama KH. Sholeh Bahruddin di Pesantren Ngalah Pasuruan," TEOSOFI: Jurnal Tasawuf dan Pemikiran Islam, Vol. 7, No. 2 (2017): 330-352, http://jurnalfuf.uinsby.ac.id/index.php/teosofi/article/view/184.

25 In the form of structured structure, the habitus is created from certain social conditions and that arena becomes a structure that has been given the shape in advance by the social conditions in which it is produced. Meanwhile, structuring structure, habitus gives shape or creates one's perceptions, representations, and actions Pierre Bourdieu, The Logic of Practice (California: Atanford University Press, 1990), 54. 
MPT'T. He clearly articulated his disagreement against the teachings of Sufism promoted by MPT'T. ${ }^{26}$

This is the condition regarding why MPT'T still exists today, even though the ideology it developed is considered controversial. Abuya Amran always refers to his father's legacy when delivering his teaching on Sufism, though the Islamic groups opposed him. The sharia groups, for instance, accused the concept of "fan $\vec{a}$ " (state of annihilation) and "baqa" (state of permanence) as "teusom hamba leumah rabbi" (none exists but Allah) as heretical. However, Abuya Amran claimed that it was derived from Abuya Muda Waly's the teusom hamba leumah rabbi poetry read on every occasion MPTT performed its tawajjuban (total submission to Allah) held weekly on every Wednesday.

\section{Identity Socialization in the Public Sphere}

MPTT strongly believes that the negative stigma assigned by the sharia groups affects the way the community views MPTT. It is because the sharia group is led by many influential figures. MPTT strives to anticipate by carrying out identity socialization in public spaces to fight for their identity. The politics of identity is always used to resist domination. The socialization was carried out to their close friends and their family members who actively participate in tawajjuhan. After founding MPTT, it began disseminating its routine activities from Labuhan Haji, many parts of South Aceh, Indonesia, and other foreign countries. The socialization of MPTT was carried out through preaching to Acehnese people. It was followed by the establishment of a more formal organizational structure to recruit new members and maintain routine activities such as dhiker and other related teachings. Furthermore, another objective of the organization was to train new members.

MPTT chief leader Abuya Amran Waly carried out the training process. It started with rateb siribee (thousand dhikrs). It was followed by a presentation of MPTT by the Aceh governor or the Wali Nanggroe (Aceh's symbolic head of state) in each city or district. In the end, it was Abuya Amran Waly who spoke about MPTT activities and the challenges it faced in promoting the Sufi teachings. All new members were allowed to ask any questions related to MPT'T. After

${ }^{26}$ Interview with The Mosque Prosperity Agency (BKM) of the Lhokseumawe Islamic Center Mosque, Banda Aceh June 2, 2019. 
being appointed by the chief leader, all regional heads were responsible for recruiting and training new members and for continuing rateb siribee.

Online media is another means of struggle of MPTT. This implies that science and technology have been used as media to be compatible with contemporary Acehnese society ${ }^{27}$ Several scholars from State Islamic University in Aceh, students, businessmen, and other professionals joining MPT'T is a proof that MPTT does not solely focus on the teachings of Sufism, but all its activities tend to revive and nurture positive attitudes, including the use of media. Therefore, Nur Ichwan views MPTT as neo Sufism. ${ }^{28}$ The link 'http://MPTTIi.com' and its YouTube channels are used as a means to publicize its organizational activities to a wider audience.

\section{Dominating Rural Mosques and Baiturrabman Grand Mosque}

A mosque for Muslims is not only considered as a religious institution but also as an integral part of Acehnese identity. Baiturrahman grand mosque is the center for religion and socioculture in Aceh $^{29}$ and a center of Muslims' religious-political perspectives. ${ }^{30}$ Similarly, MPTT also spread their teachings from one mosque to another. The MPT'T activities were obviously carried out in Banda Aceh and Aceh Besar. Tgk. Syukri revealed that the first MPTT activity was held at Gampong Pango mosque in Banda Aceh. However, the community later opposed the teaching after MPTT was accused of heresy. The teaching resumed after Tgk. Syukri and others joined MPTT, and Gampong Pango turned to be the strong basis for MPT'T.

After being well established with many numbers of followers, it was Tgk. Syaukri attempted to facilitate MPTT to perform activities at Baiturrahman grand mosque in Banda Aceh. However, the plan was rejected by the Mosque Prosperity Agency (BKM) without any further

\footnotetext{
27 IT., Rijal, and Hudi Prasojo, "Sufism and Religious Practices in Modern Lifestyle".

${ }^{28}$ Ichwan, "Neo-Sufism, Shariatism, and Ulama Politics".

${ }^{29}$ Julie Nichols, "Parallel Processes: Spatial Production at Aceh's Baiturrahman Mosque," International Journal of Islamic Architecture, Vol. 8, No. 1 (2019), 169-199, https://www.ingentaconnect.com/content/10.1386/ijia.8.1.169_1.

30 Syaifudin Zuhri, "The Mosque as the Religious Sphere: Looking at the Conflict over the Al Muttaqun Mosque," in Kees van Dijk and Nico J.G. Kaptein (eds.), Islam, Politics, and Change (Leiden: Leiden University Press, 2016), 82-94.
} 
clarification. MPTT used the rejection to strengthen its influence by performing religious activities in many mosques around Banda Aceh and Aceh Besar. After a significant increase of the followers, MPTT through Tgk. Syukri was welcomed to deliver their activities at Baiturrahman grand mosque. However, it was not until three times the request was granted by the Mosque Prosperity Agency.

The first meeting of MPTT garnered public attention because of its ability to gather the MPTT members from various regions, including Jakarta and North Sulawesi. The number of people attending the meeting was marked by the presence of thousands of people. For MPTT, the religious meeting at Baiturrahman grand mosque demonstrates a large number of people who attended the meeting and showed the legality of its political perspectives. This was strengthened through the choice of administering the meeting at Baiturrahman grand mosque, which stands for the pride of the Acehnese people and the Acehnese Islamic icon with its rich historical value. It also shows that it was the first official event of MPTT religious activities at the provincial level. This gradually signifies the growing positive impact on MPTT. From this success, MPT'T began spreading its influence on a wider audience outside Aceh.

\section{Building Political Alliances}

Another form of the politics of identity exercised by MPTT is seeking political support from the local government and political parties. Nur Ichwan states that any support from the government benefits an organization, be it organizational legality or the protection from the negative consequences of sharia groups ${ }^{31}$ Furthermore, Tgk. Syukri said that H. Ramli's joining benefits MPTT. He was the West Aceh regent. This close relation paves the way for MPTT to disseminate the tauhid tasammuf teachings and facilitate the first mudhakarah (Sufi meeting) in the region. It was a relationship that mutually benefited each other. By joining MPTTI, the regent was able to garner support from MPTT. The support from MPTT helped the regent to implement the regent's regulation regarding the prohibition

${ }^{31}$ Ichwan, "Neo-Sufism, Shariatism, and Ulama Politics". 
of women wearing tight pants in public places, which were considered controversial. $^{32}$

Abu Amran Waly strengthened his relationship with the Southwest Aceh regent, Akmal Ibrahim from 2017 to 2022. Abu Amran well knew Akmal Ibrahim when Akmal was nominated as a candidate to contest for the regent. This shows the mutual benefits in establishing the relationship. Abu Amran openly supported Akmal Ibrahim's candidacy for Southwest Aceh regent. Akmal Ibrahim facilitated MPTT to hold an international conference on Sufism in Blang Pidie. Abu Amran had a close relationship with the political alliances with Gayo Lues regent, Husein Yusuf, the Subulussalam mayor, and the West-South regent. Through this relation, the mayor stated to grant funding for rateb siribee.

However, MPTT was challenged to build a political alliance in East-North Aceh because of a strong influence of sharia groups, the district heads and the mayors coming from the Aceh Party (a local party) favored MUNA (Ulema Council of Nanggroe Aceh), HUDA (Dayah Ulema Association of Aceh), and MPU (Ulema Consultative Council) as the sharia groups representatives. Nur Ichwan said that although HUDA, MUNA, and MPU have different interpretations, all three organizations opposed MPTT. ${ }^{33}$ In Bireuen, MPTT failed to build relationships with Nurdin Abdurrahman (2007-2012) and Ruslam Daud (2012-2017). Both were from the Aceh Party. When Bireun was under Saifannur's administration (2017-2022), the restriction of MPT'T was relaxed because of the sympathy of Saifannur towards MPTT. However, Saifannur had never been a loyal supporter of MPTT.

The same condition occurred in Pidie, Pidie Jaya, North Aceh, and East Aceh, where the sharia groups had a strong influence. When north Aceh was under Yahya's administration (2012-2017 and 20172022), he showed a more friendly attitude towards MPTT. Through Labuhan Haji Islamic boarding school's alumni board, the mayor allowed MPTT to hold its religious activities at the Masjid Islamic Center, Lhokseumawe, North Aceh. The MPPT activities were also banned in Langsa. It can be seen through the cancellation of the proposed activities due to threats from sharia groups. The planned

\footnotetext{
32 Interview with Tgk. Syukri (Chair of the MPTT Aceh Besar-Banda Aceh Region), Banda Aceh, June 28, 2019.

${ }^{33}$ Ichwan, "Neo-Sufism, Shariatism, and Ulama Politics".
} 
religious activity at Merdeka Square on August 27, 2018, was canceled.

The situation faced by MPTT implies that the success and the failure of an organization are strongly influenced and determined by the political alliances at any level. It shows that when the community accepts MPPTI, there is a strong bond between MPTT and the local administration. As a sequence of this harmonious tie, MPTT was facilitated and financially supported by the local government to perform its tauhid tasawnuf and rateb siribee. Conversely, when there is a strong rejection in a region, it is difficult to build a strong relationship with the regional heads, as in the dynamics in East-North Aceh. The same condition also occurs at the provincial level. After the memorandum of understanding between the Free Aceh Movement (GAM) and the Indonesian administration, many regions were ruled by political figures from the Aceh Party who were rooted in the Free Aceh Movement. In religious affiliations, the Aceh Party strongly followed MUNA. Even though MUNA and HUDA differ in some respects, they came with the same consensus to ban MPT'T's tauhid tasawnuf.

Because MUNA has a strong influence on the Aceh Party, it becomes difficult for MPTTI to build a harmonious relationship with the Aceh government. This is understandable that Abu Amran did not have a strong relationship with Irwandi Yusuf and Muhammad Nazar (2007 - 2011). Irwandi Yusuf and Muhammad Nazar were very close to Abuya Muhibbuddin Waly, a MUNA advisor. Furthermore, during Zaini and Muzakkir Manaf (2012-2017) leadership, it was difficult for Abu Amran to exert political influence on the two leaders. This is because MUNA strongly had a strong influence on the political figures in Aceh. In other words, the stronger the sharia groups become, the more difficult for MPT'T to disseminate its teachings. This can be seen from the heating debate and long negotiation between MPTT and the Aceh administration to carry out rateb siribee at the Baiturrahman grand mosque, emphasizing the recitation of the names of Allah rather than its tauhid tasawnuf.

When Irwandi Yusuf and Nova (2017-2022) came to power for the second term, they were supported by the Nanggroe Aceh Party (PNA). Therefore, the role and the influence of the Aceh Party have decreased, while MUNA and HUDA did not significantly influence Irwandi. Seeing this broken tie, MPTT gradually attempted to 
establish a strong relationship with the provincial government. It was seen through strong support from MPTT to back Irwandi's candidacy. The outstanding mark of this close relationship between MPTT and Irwandi was materialized through the administration of an international conference on Sufism (mudhäkarah) in Banda Aceh. The government did grant permission and supported the event financially from the Aceh Revenue and Expenditure Budget (APBA). It was also very clear that that the sharia groups attempted to influence Irwandi Yusuf to revoke the MPTT permit and persuade the Dayah Board to ask MPTT to remove MPT'T's banners. The main objective of MPT'T was to hold mudhäkarah attended by Sufi ulemas from various countries.

\section{Tarekat, Networking, and Identity Affirmation}

There is always a challenge to form a relationship between groups of different identities. It is very often that the relationship can lead to a cultural shock as a common consequence. Culture shock occurs in the relation between two groups of the same background are easy to be compromised and coped with. The relationship between two groups of different identities leads to the complexity which requires negotiations. It is commonly found that such a relationship generates contestation. ${ }^{34}$ MPTT could not find it easy to build a relationship with other sharia groups. Each group tries to strengthen its own identity. However, MPTT feels connected with Kadirun Yahya community because both groups have the same identity. When the sharia groups in Langsa rejected MPTT, it was warmly welcomed by Qadirun Yahya' the tarekat Naqshabandiyya. It was also noted that Qadirun Yahya's sufism was considered heretical.

The relationship between MPTT and Qadirun Yahya's Naqshabandiyya shows strong solidarity. This solidarity strengthens their identity, even though both are minorities. When the majority group threatened MPTT, the Qadirun Yahya community gave strong support. Qadirun Yahya's followers believe that depending MPTT means fighting for the truth. The other local, national, and international Sufi's groups also provided strong supports for MPTT, such as Rahimuddin Nawawi (the author al-Ubüdiyya al-Nawawi alBantani), Syah Jen Janurji (a great Islamic scholar of West Java), and

\footnotetext{
34 Stella Ting-Toomey, Communication Across Cultures (London: The Guldford Press, 1999), 29.
} 
Sheikh Muhammad Saleh. Through this strong support, MPTT becomes stronger both locally and nationally.

The strong relationship between MPTTI and other tarekat networks in Aceh and the rest of Indonesia can be traced back to the gathering of tarekat ulema in Medan. After the meeting, MPTT was seen as part of their struggle and deserved to be assisted in fighting against the majority's discrimination and domination. Therefore, to intensify the relationship, Abu Amran frequently visited other Sufi ulemas in many regions. On September 28, 2018, MPTT paid a visit to Sheikh Alaidarus in Pekanbaru, Riau. On October 17, 2019, Abu Amran visited West Sumatra and conducted rateb siribee. Other places visited by Abu Amran include West Java, Bali, Lampung, Jakarta, and other cities. It is from this regular visit of Abu Amran, MPT'T began to be internationally recognized. Abu Amran's visit can be divided into three phases. The first phase was marked by his regular to other Sufi figures that further strengthened the MPTT network. This visit helped MPTT to build a wider network to Southeast Asian countries. The second phase was his visit to neighboring countries, Malaysia and Patani, Thailand, to introduce the existence of MPTT and find an international network and establish MPT'TI's chapters. The international recognition of MPTT can be seen through the mudhäkarah activities held in Kuala Lumpur in 2012. The third phase was marked by the ability of MPTT to connect to the world. The arrival of Iranian Sufi ulema to meet Abu Amran Wali was proof that shows the strong connection of MPT'T to the world. Even though Abu Amran, according to Tgk. Syukri has never visited Iran.

\section{Connection to University Students}

The practice of the politics of identity of MPTT was carried out by promoting MPTT to university students. This relationship is not on an individual basis, but rather through the Students Executive Board (BEM), or the Department Students Association (HMP), or Faculty Students Association (HMJ). The university students had facilitated MPTT activities, especially rateb siribee. For instance, the students of State Islamic University, Ar-Raniry, actively participated in rateb siribee organized by the Aceh Police Headquarters in Jeulingke, Banda Aceh. The students of Teuku Umar University and Tengku Dirundeng State Islamic College in Meulaboh also actively took part 
in the rateb siribee organized by the West Aceh government in collaboration with the two universities.

Apart from the three universities mentioned, MPTT continued making a stronger connection with other universities, including the State Islamic Institute for Islamic Studies, Langsa. However, this alliance was challenged by the sharia groups that finally failed the MPT'TI's effort to cooperate with the students. The negative stereotype assigned to MPTT has been another factor that can explain the failure of this connection. The planned rateb siribee that was supposed to take place at Merdeka Square, Langsa was banned and canceled. The effort of MPTT to involve students can be read as an MPT'T strategy that targets the students and the university institutions as the growing numbers of university academics joined MPT'T. This can be seen from the rateb siribee banner and the study of tauhid tasawnuf included in the Ushuluddin faculty curriculum, State Islamic University, Ar-Raniry, Banda Aceh.

\section{Rateb Sirebee: Forming Communities, Strengthening Identity, and Building Solidarity}

Rateb siribee is a dbikr activity that is always read out at every meeting at the local, provincial, national, and international levels. The use of this rateb siribee currently is seen as the representation of religiosity and is used to attract the people's attention to involve in MPTT. This is because dhikr signifies an alternative to being a devout Muslim. Dhiker is understood not only as representing a vertical relation to Allah but also as a way to find a solution for the complexities people face ${ }^{35}$ particularly for the modern people who are obsessed with worldly things often find spiritual emptiness. ${ }^{36}$

The dhikr carried out by MPTT is popularly known as "rateb siribee". It is important because it promotes self-purification (taqarrub) and to attain a noble behavior. Rateb siribee (thousand dbikrs) is also to increase solidarity and strengthen identity. This solidarity indicates a strong relationship among MPT'T members and with other communities. The rateb siribee was internally performed at MPTT

35 Sulaiman, "Tasawuf Lokal Panglima Utar di Kotawaringin Barat, Kalimantan Tengah," IBDA: Jurnal Kajian Islam dan Budaya, Vol. 15, No. 1 (2017), 199, http://ejournal.iainpurwokerto.ac.id/index.php/ibda/article/view/1037.

${ }^{36}$ Shinta Nurani, "Urban Sufism and Transformation of Islamic Culture in Millenial Society," RELIGLA, Vol. 21, No. 2 (2018): 158, http://e-journal.iainpekalongan.ac. id/index.php/Religia/article/view/1508. 
offices to strengthen relations among the followers. There are two kinds of internal rateb siribee; the chief leader of MPT'T administered one and the other one was conducted by the Wali Nanggroe. The rateb siribee led by murabbi (the chief leader of MPTT) was performed at regional offices attended by all members from various regions, while the rateb siribee under the wali nanggroe is usually held in certain areas. The rateb siribee can also be performed indoor or outdoor.

The rateb siribee held in collaboration with other communities was to increase a strong relationship with other communities. This performance was facilitated by institutions. When performing rateb siribee in Subulussalam, it was attended by all MPTT members and all local government staff. Similarly, the local government of Medan and Binjai City, North Sumatra, financially facilitated the performance of rateb siribee in their cities and in the penitentiaries. The rateb siribee was also performed in Banda Aceh held by Aceh Regional Police Headquarters in collaboration with MPTTI and State Islamic University, Ar-Raniry.

The success of conducting rateb siribee in many places implies the ability of MPTT to strengthen its identity. The existence of MPT'T promoting rateb siribee received strong appreciation from many government institutions and other organizations. The rateb siribee held at Aceh Police Headquarters signifies its ability to challenge the negative stigma of heretical by the sharia groups by showing that the religious activity of rateb siribee is repeatedly recited the name of Allah. The rateb siribee held internally represents its existence, and it also turns to be a means of recruiting new members.

The religious activity conducted by MPTT is used as a means to garner social recognition. By this recognition, MPTT is no longer subdued as subordinate but fully plays a significant role within the religious discourses. Abuya Amran firmly and repeatedly stated that MPTT does not contradict Tastafi ${ }^{37}$ but focuses more deeply on religious practices. Also, Tastafi teaches tauhid based on scientific studies, while MPTT includes mystical elements in its interpretation of religious activities. In short, to fully understand tauhid tasawnuf, an adequate and appropriate understanding of the basic tauhid is clearly

\footnotetext{
${ }^{37}$ The term "Tastafi" council for the Study Tauhid, Tasawuf, and Fiqh. This Group is a match "MPT"T".
} 
required. ${ }^{38}$ Because of the harsh rejection of the sharia groups, MP'TI has used the politics of identity as its means of struggle.

\section{Strengthening Identity in Public Spaces}

The activities carried out by MPTT can be interpreted as a form of its political identity to fight for the negative stigma of the sharia groups against its religious ideology. The politics of identity of MPTT significantly influenced the government's recognition both at the provincial level and regional levels. The mudhäkarah of International Sufi scholars and rateb siribe held in Banda Aceh indicates the acceptance of MPTT at provincial and mudhäkarah as well as rateb siribee at regional levels. Apart from its strong influence on the government, MPTT also received support from the police, judiciary, and other government offices and non-government organizations. The form of the institutional support for MPTT was seen through the facilitated rateb siribee and tauhid tasawnuf teaching at Aceh Regional Police Headquarters and Aceh Besar Penitentiary.

The politics of identity of MPTT also has significantly influenced the religious ideology of some communities at the local, national, and international levels. This can be seen through the increasing numbers of the members in Aceh, Sumatra, Java, Manado, Gorontalo, Malaysia, and Pattani, Thailand. It is also marked by the growing enthusiasm of the people to attend tauhid tasawwuf and rateb siribee. This shows that the politics of identity practiced by MPTT strengthens its identity in socio-religious life. This phenomenon indicates that MPTT has significantly transformed the way people view and perform religious practices.

However, the emergence MPTT remains controversial up to this day. The sharia ulemas still show their opposing stance against MPTT's religious identity. The sharia ulemas also have not initiated any opportunities bridging positive dialogue with MPTT. This condition has an impact on the religious dynamics and the coexistence of both MPTT and the Sharia Ulema.

\footnotetext{
38 Statement by Abuya Amran Wali when addressing the study of tauhid tasawuf in Langsa City, August 27, 2018 on St. TM Bahrum Paya Bujok Seulemak, Langsa Baro, Langsa City.
} 


\section{Concluding Remarks}

Based on the findings above, it is concluded that MPT'T struggles against discrimination, subordination, and social rights restrictions. Even though they are discriminated against as being viewed as heretical, MPTT can develop at the local, national, and international levels. The existence of MPTT branches outside Aceh and its strong relationship with worldwide Sufi ulema is an extraordinary achievement. This can be achieved through the struggle against injustice from the politics of identity politics practiced by sharia groups.

MPTT had practiced forms of the politics of identity in seeking its Islamic identity. These can be generally classified into religious, social, political, and cultural spaces. In the religious space, the dissemination of Sufism's practice is the main goal of the MPTT religious movement. The practice of MPTT religious rituals at Baiturrahman grand mosque represents its own identity to a wider audience. In the social space, the relationship of MPT'T with the other Sufi ulemas, alumni associations, and the university students strengthens its social identity. Makin alliances with the regional and provincial administration is another form of the politics of identity employed by MPTT. The use of rateb siribee has strengthened its identity both religiously and culturally. Rateb siribee is religious because it is part of religious orders.

The politics of identity practiced by MPT'T fighting for its rights has been mainly achieved. MPTT gradually but certainly removes the negative stigma shown by the recognition of regional and provincial government. However, MPTT has not been fully acknowledged by the sharia ulema. This situation brings another impact on the socio-religious groups and the disharmony among the religious groups.

\section{References}

\section{A. Book/Journal}

Abbas, Moh. Rafli. "Ruang Publik dan Ekspresi Politik Identitas: Studi tentang Pergulatan Identitas Ke-Papua-an di Yogyakarta)," Society, Vol. 4, No. 1, 2016. https://society.fisip .ubb.ac.id/index.php/society/article/view/33.

Börzel, Tanja A. and Risse, Thomas. "Identity Politics, Core State Powers, and Regional Integration: Europe and Beyond," JCMS: 
Journal of Common Market Studies, Vol. 58, No. 1, 2020. https://onlinelibrary.wiley.com/doi/abs/10.1111/ jcms.12982.

Bourdieu, Pierre. The Logic of Practice. California: Atanford University Press, 1990.

Brunila, Kristiina and Rossi, Leena-Maija. "Identity Politics, the Ethos of Vulnerability, and Education," Educational Philosophy and Theory, Vol. 50, No. 3, 2018. https://www.tandfonline.com /doi/full/10.1080/00131857.2017. 1343115.

Connolly, Peter. Aneka Pendekatan Studi Agama. Yogyakarta: LKiS, 2002.

Hill, Michael. "Sect", Encyclopedia of Religion. New York: Simon \& Schuster Macmillan, 1996.

Ichwan, Mohd Nur. "Neo-Sufism, Shariatism, and Ulama Politics: Abu Shaykh Amran Waly and the Tauhid-Tasawuf Movement in Aceh", in Kees van Dijk and Nico J.G. Kaptein (eds.), Islam, Politics and Change. Leiden: Leiden University Press, 2016.

Khamdan, Muh. and Wiharyani, Wiharyani. "Mobilisasi Politik Identitas dan Kontestasi Gerakan Fundamentalisme," al-Tabrir: Jurnal Pemikiran Islam, Vol. 18, No. 1, 2018. http:// jurnal.iainponorogo.ac.id/index.php/tahrir/article/view/ 1198.

Maarif, Ahmad Syafii. "Politik Identitas dan Masa Depan Pluralisme Indonesia," in Ihsan Ali-Fauzi dan Samsu Rizal Panggabean (eds.), Politik Identitas dan Masa Depan Pluralisme. Jakarta: Democracy Project, 2012.

Makin, Al. "Returning to the Religion of Abraham: Controversies over the Gafatar Movement in Contemporary Indonesia," Islam and Christian-Muslim Relations, Vol. 30, No. 1, 2019. https:// www.tandfonline.com/doi/full/10.1080/09596410.2019.15704 25.

Nafis, Muhammad Muntahibun and Najib, Muhammad Ainun. "Pemikiran Sufistik dan Toleransi Beragama KH. Sholeh Bahruddin di Pesantren Ngalah Pasuruan," TEOSOFI: Jurnal Tasawnf dan Pemikiran Islam, Vol. 7, No. 2, 2017. http:// jurnalfuf.uinsby.ac.id/index.php/teosofi/article/view/184.

Nichols, "Parallel Processes: Spatial Production at Aceh's Baiturrahman Mosque," International Journal of Islamic Architecture, Vol. 8, No. 1, 2019. https://www.ingentaconnect.com/content /10.1386/ijia.8.1.169_1. 
Nurani, Shinta. "Urban Sufism and Transformation of Islamic Culture in Millenial Society," RELIGIA, Vol. 21, No. 2, 2018. http://e-journal.iainpekalongan.ac.id/index.php/Religia/article /view/1508.

Observation of Participants in the Study of Tauhid Tasawuf and Rateb Siribee at the Islamic Center Lhokseumawe, August 13, 2017

Rahmawati., Yahiji, Kasim., and Mustakimah. "Makna Zikir Bagi Jemaah Tarekat Naqshabandīyah Khālīdīyah Majelis Pengkajian Tauhid Tasawuf Indonesia di Kota Gorontalo," TEOSOFI: Jurnal Tasawnf dan Pemikiran Islam, Vol. 8, No. 2, 2018. http://jurnalfuf.uinsby.ac.id/index.php/teosofi/article/view/2 34.

Shadiqin, Sehat Ihsan. "Tasawuf di Era Syariat: Tipologi Adaptasi dan Tranformasi Gerakan Tarekat dalam Masyarakat Aceh Kontemporer," Jurnal Substansia, Vol. 20, No. 1, 2018.

Sulaiman. "Tasawuf Lokal Panglima Utar di Kotawaringin Barat, Kalimantan Tengah," IBDA: Jurnal Kajian Islam dan Budaya, Vol. 15, No. 1, 2017. http://ejournal.iainpurwokerto.ac.id /index.php/ibda/article/view/1037.

Suraiya IT., Rijal, Syamsul., and Prasojo, Zaenuddin Hudi. "Sufism and Religious Practices in Modern Lifestyle," Religió: Jurnal Studi Agama-agama, Vol. 9, No. 1, 2019. http://jurnalfuf.uinsby.ac.id /index.php/religio/article/view/1231.

Ting-Toomey, Stella. Communication Across Cultures. London: The Guldford Press, 1999.

Zuhri, Syaifudin. "The Mosque as the Religious Sphere: Looking at the Conflict over the Al Muttaqun Mosque," in Kees van Dijk and Nico J.G. Kaptein (eds.), Islam, Politics, and Change. Leiden: Leiden University Press, 2016.

\section{B. Interview}

Interview with Tgk. Syukri (Chair of the MPTT Aceh Besar-Banda Aceh Region). Banda Aceh, June 28, 2019.

Interview with Tgk. Usman (an alumnus of the Darussalam Labuhan Haji Islamic Boarding School in South Aceh, as well as the Implementation of the Tauhid Tasawuf and Rateb Siribee Study Activities at the Islamic Center Lhokseumawe). Banda Aceh August 13, 2017. 